\title{
Characterization of a New Ezakiella Isolated from the Human Vagina: Genome Sequence and Description of Ezakiella massiliensis sp. nov.
}

\author{
Khoudia Diop $^{1}$ - Claudia Andrieu ${ }^{1} \cdot$ Caroline Michelle $^{1} \cdot$ Nicholas Armstrong $^{1} \cdot$ Fadi Bittar $^{1} \cdot$ Florence Bretelle $^{1,2}$. \\ Pierre-Edouard Fournier ${ }^{1}$. Didier Raoult ${ }^{1,3} \cdot$ Florence Fenollar $^{1}$
}

\begin{abstract}
The study of the vaginal microbiota using the "culturomics concept" allowed us to isolate, from the vaginal swab of an asymptomatic 20-year-old woman who had sexual relations with another woman with bacterial vaginosis, an unknown Gram-positive anaerobic coccus-shaped bacterium that was designated strain Marseille-P2951 ${ }^{\mathrm{T}}$ and characterized using taxono-genomics. Strain Marseille-P2951 ${ }^{\mathrm{T}}$ is non-motile and non-spore forming and exhibits catalase and oxidase activities. Its 16S rRNA gene-based identification showed 98.5\% identity with Ezakiella peruensis, the phylogenetically closest species. The major fatty acids are $\mathrm{C} 18: \ln 9(58 \%)$ and $\mathrm{C} 16: 0$ (22\%). With a 1,741,785 bp length, the G+C content of the genome is $36.69 \%$. Of a total of 1657 genes, 1606 are protein-coding genes and 51 RNAs. Also, 1123 genes are assigned a putative function and 127 are ORFans. Phenotypic, phylogenetic, and genomics analyses revealed that strain MarseilleP2951 ${ }^{\mathrm{T}}$ (=CSUR P2951 =DSM 103122) is distinct and represents a new species of the genus Ezakiella, for which the name Ezakiella massiliensis sp. nov. is proposed.
\end{abstract}

\section{Introduction}

Gram-positive anaerobic cocci are mainly represented by the Peptostreptococci. These bacteria are part of the commensal flora of humans and animals, and are also often associated with a variety of human infections [21]. They represent approximately $24-31 \%$ of all anaerobic bacteria isolated in clinical samples and are the most frequent species

Florence Fenollar

florence.fenollar@univ-amu.fr

1 Aix-Marseille Univ, Unité de Recherche sur les Maladies Infectieuses et Tropicales Emergentes, AMU UM 63, CNRS UMR7278, IRD 198, INSERM U1095, Institut HospitaloUniversitaire Méditerranée-Infection, Faculté de Médecine, 19-21 Boulevard Jean Moulin, 13005 Marseille Cedex 05, France

2 Department of Gynecology and Obstetrics, Gynépole, Marseille, Hôpital Nord, Assistance Publique-Hôpitaux de Marseille, AMU, Aix-Marseille Université, Marseille Cedex 05, France

3 Special Infectious Agents Unit, King Fahd Medical Research Center, King Abdulaziz University, Jeddah, Saudi Arabia that belong to the genus Peptostreptococcus [20]. A taxonomic revision of this group has occasioned the division of Peptostreptococcus into 5 genera: Anaerococcus, Finegoldia, Gallicola, Parvimonas, and Peptoniphilus [8]. In 2015, a new genus of Gram-positive anaerobic cocci called Ezakiella was identified from a human fecal sample in a coastal traditional community in Peru [24, 25]. This genus has only one species: Ezakiella peruensis [16]. In a study characterizing the vaginal flora of women with and without bacterial vaginosis using the "culturomics concept," based on the multiplication of culture conditions (media, temperature, $\mathrm{pH}$, and atmosphere) combined with rapid bacterial identification by Matrix-assisted laser desorption/ionization time-of-flight (MALDI-TOF) mass spectrometry (MS) [13, 14], we identified an unknown strain of Ezakiella designated Marseille-P2951 ${ }^{\mathrm{T}}$ which did not correspond to the other species of this genus.

We report the phenotypic, phylogenetic, and genomic characteristics of Ezakiella massiliensis sp. nov., strain Marseille-P2951 ${ }^{\mathrm{T}}(=$ CSUR [Collection de souches de l'Unité des Rickettsies] P2951 = DSM [Deutsche Sammlung von Mikroorganismen] 103122), isolated from the vaginal sample of a healthy woman who had sexual relations with another woman with bacterial vaginosis. 


\section{Materials and Methods}

\section{Ethics and Sample Collection}

In October 2015, a vaginal sample from an asymptomatic 20-year-old woman who had sexual relations with another woman with bacterial vaginosis was collected at the Hospital "La Timone" in Marseille (France). The diagnosis was conducted as previously reported [18]. At the time of sample collection, she was not being treated with antibiotics. She gave her written consent. This study was authorized by the local IFR48 ethics committee (Marseille, France) under agreement number 09-022. The sample was collected and transported using a Sigma Transwab (Medical Wire, Corsham, United Kingdom).

\section{Strain Identification by MALDI-TOF MS and 165 rRNA Gene Sequencing}

After sampling, the vaginal specimen was cultured using 1 of the 18 culturomics conditions previously described [14]. Isolated colonies were identified using MALDI-TOF, as previously described [4, 5, 28]. For unidentified colonies, the $16 \mathrm{~S}$ rRNA gene was sequenced and the obtained sequence was matched against the NCBI database using the BLAST algorithm [7]. As suggested, if the 16S rRNA gene sequence similarity value was $<98.7 \%$, the strain was defined as a new species [12, 29].

\section{Phylogenetic Tree}

All species from the same order of the new species were retrieved and $16 \mathrm{~S}$ sequences were downloaded from NCBI. Sequences were aligned using CLUSTALW, with default parameters and phylogenetic inferences obtained using the neighbor-joining method with 500 bootstrap replicates, using MEGA6 software.

\section{Morphologic and Biochemical Characterization}

To observe cell morphology, individual cells were visualized using a Tecnai G20 electron microscope [4]. Oxidase and catalase tests, Gram stain, motility, and sporulation were performed as previously conducted [23]. Biochemical tests were performed using API ZYM, API 20A, and API 50CH strips (bioMérieux, Marcy l'Etoile, France).

\section{Growth Conditions}

To determine optimal growth, the strain Marseille-P2951 ${ }^{\mathrm{T}}$ was cultivated on Columbia agar with $5 \%$ sheep blood (bioMérieux) and incubated at different temperatures in aerobic, anaerobic, and microaerophilic atmospheres [4, 5]. The salinity and $\mathrm{pH}$ conditions were also tested $[4,5]$.

\section{Cellular Fatty Acid Analysis}

Cellular fatty acid methyl ester (FAME) analysis was performed by Gas Chromatography/Mass Spectrometry (GC/ MS). Strain Marseille-P2951 ${ }^{\mathrm{T}}$ was grown on Columbia agar (bioMérieux). Then, two samples were prepared with approximately $9 \mathrm{mg}$ of bacterial biomass per tube harvested from several culture plates. FAME was prepared as described by Sasser [27]. GC/MS analyses were carried out as described before [3]. Briefly, fatty acid methyl esters were separated using an Elite 5-MS column and monitored by mass spectrometry (Clarus 500_-SQ 8S, Perkin Elmer, Courtaboeuf, France). A spectral database search was performed using MS Search 2.0 operated with the Standard Reference Database 1A (NIST, Gaithersburg, USA) and the FAMEs mass spectral database (Wiley, Chichester, UK).

\section{Antibiotic Susceptibility Testing}

Amoxicillin, benzylpenicillin, ceftriaxone, imipenem, metronidazole, and vancomycin were used to test antibiotic susceptibility of strain Marseille-P2951 ${ }^{\mathrm{T}}$. The minimal inhibitory concentrations (MICs) were then determined using E-test gradient strips (bioMérieux) [1, 17].

\section{DNA Extraction, Genome Sequencing, and Assembly}

After a pre-treatment of $2 \mathrm{~h}$ with lysozyme incubation at $37{ }^{\circ} \mathrm{C}$, genomic DNA (gDNA) of strain Marseille-P2951 ${ }^{\mathrm{T}}$ was extracted on the EZ1 biorobot (Qiagen) with the EZ1 DNA tissue kit. The elution volume was $50 \mu \mathrm{L}$. gDNA was quantified by a Qubit assay with the high sensitivity kit (Life technologies, Carlsbad, CA, USA) at $74.2 \mathrm{ng} / \mu \mathrm{L}$.

Then gDNA was sequenced on MiSeq Technology (Illumina Inc, San Diego, CA, USA) with the mate pair strategy. The gDNA was barcoded in order to be mixed with 11 other projects with the Nextera Mate Pair sample prep kit (Illumina) $[4,5]$. Then, the genome sequencing and assembly were performed as previously described [4]. The reads were trimmed and assembled using the CLC genomics Workbench v4.7.2 software (CLC bio, Aarhus, Denmark).

\section{Genome Annotation and Analysis}

The Multi-Agent software system DAGOBAH [10] was used to perform annotation and comparison processes, which include Figenix [11] libraries that provide pipeline analysis. The genome of strain Marseille-P2951 ${ }^{\mathrm{T}}$ was compared to those of closest species. In order to evaluate the genomic similarity among all compared genomes, two parameters 
were determined: dDDH, which exhibits a high correlation with DNA-DNA Hybridization (DDH) [19], and AGIOS (Average Genomic Identity of Orthologous gene Sequences) [26], which was designed to be independent from DDH.

\section{Results}

\section{Strain Identification and Phylogenetic Analysis}

The MALDI-TOF MS identification of our isolate failed (score $<1.7$ ). The 16S rRNA gene sequence of the strain showed $98.5 \%$ identity with Ezakiella peruensis, the phylogenetically closest species with a validly published name (Fig. 1). As this value was $<98.7 \%$ recommended to delimited a species $[12,29]$, the strain Marseille-P2951 ${ }^{\mathrm{T}}$ was classified as a new species, named Ezakiella massiliensis sp. nov. The reference spectrum (Fig. 2a) was incremented in our database (http://www.mediterranee-infection.com/article.php?laref $=256 \&$ titre $=$ urms-database) and then compared to other closest species; their differences are shown in the gel view obtained (Fig. 2b).

\section{Phenotypic and Biochemical Characteristics}

Strain Marseille-P2951 ${ }^{\mathrm{T}}$ is a Gram-positive anaerobic coccus, $0.7 \mu \mathrm{m}$ in diameter (Supplementary Figure S1A and B), non-motile, and non-spore forming. After 3 days of growth on blood agar (BD diagnostic), colonies were clear and gray, circular, and convex, with a diameter of approximately $0.8 \mathrm{~mm}$. This strict anaerobe grows at temperatures between 28 and $37{ }^{\circ} \mathrm{C}$, but optimal growth was observed at $37{ }^{\circ} \mathrm{C}$ after $48 \mathrm{~h}$ of incubation. Bacterial growth requires a $\mathrm{NaCl}$ concentration $<5 \mathrm{~g} / \mathrm{L}$ and a $\mathrm{pH}$ ranging from 6.5 to 8.5. Strain Marseille-P $2951^{\mathrm{T}}$ exhibited catalase and oxidase activities, whereas nitrate and nitrite were not reduced. The results of the API ZYM, 20A, and 50CH are summarized in Table 1 and were compared to those of the closest species $[2,8,22,25,30]$. The fatty acid profiles of strain Marseille$\mathrm{P} 2951^{\mathrm{T}}$ and the closest species are recapped in Table 2. Strain Marseille-P2951 ${ }^{\mathrm{T}}$ was susceptible to amoxicillin (MIC $0.016 \mu \mathrm{g} / \mathrm{mL}$ ), benzylpenicillin (MIC $0.003 \mu \mathrm{g} / \mathrm{mL}$ ), ceftriaxone (MIC $0.016 \mu \mathrm{g} / \mathrm{mL}$ ), imipenem (MIC $0.032 \mu \mathrm{g}$ / $\mathrm{mL}$ ), metronidazole (MIC $0.047 \mu \mathrm{g} / \mathrm{mL}$ ), and vancomycin (MIC $0.19 \mu \mathrm{g} / \mathrm{mL}$ ).

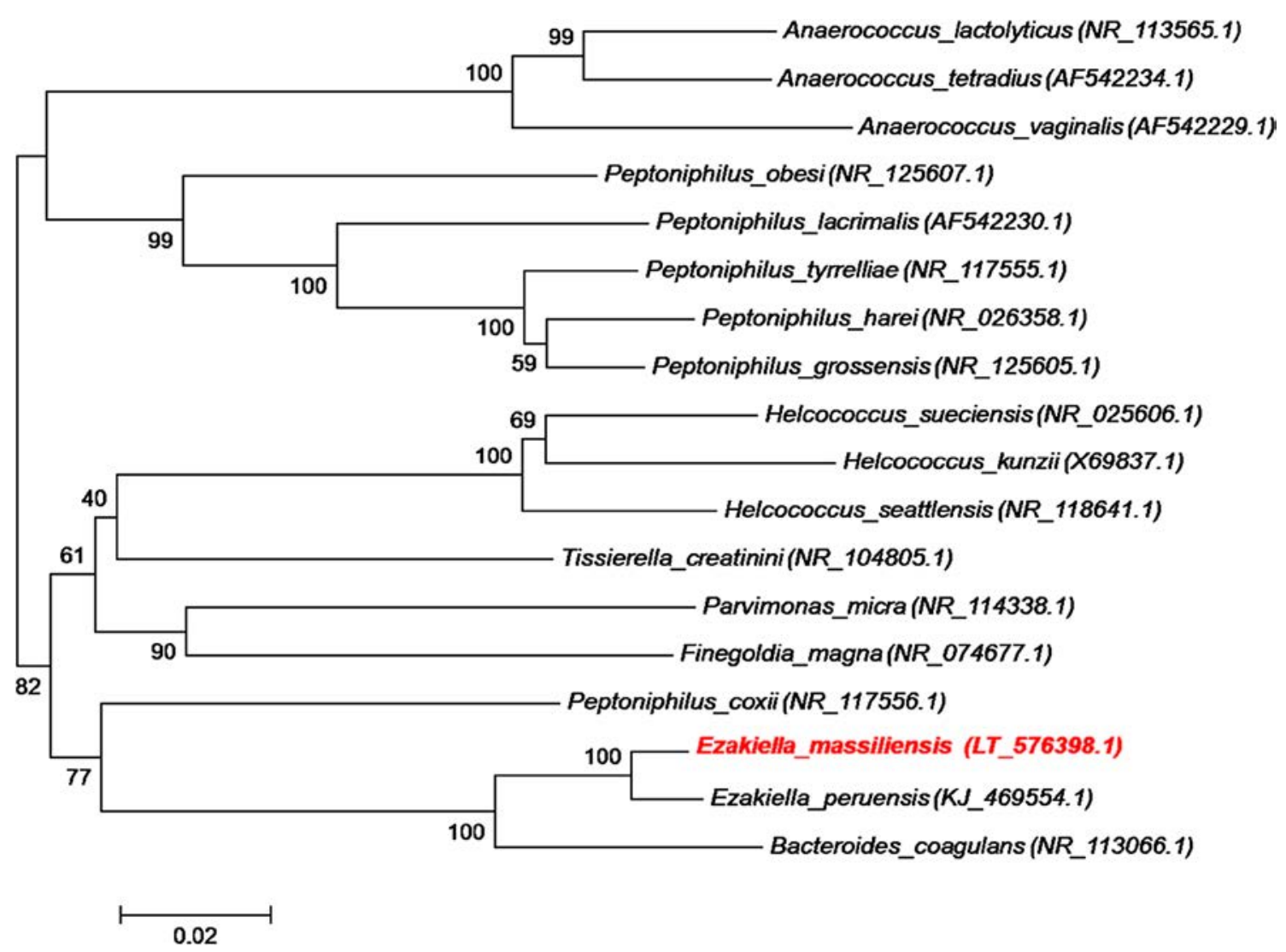

Fig. 1 Phylogenetic tree highlighting the position of Ezakiella massiliensis strain Marseille-P2951 ${ }^{\mathrm{T}}$ relative to other close strains. GenBank accession numbers for each 16S rRNA are noted in parenthesis. Sequences were aligned using Muscle v3.8.31 with default param- eters and phylogenetic inferences were obtained using the neighborjoining method with 500 bootstrap replicates, using MEGA6 software. The scale bar represents a $2 \%$ nucleotide sequence divergence 


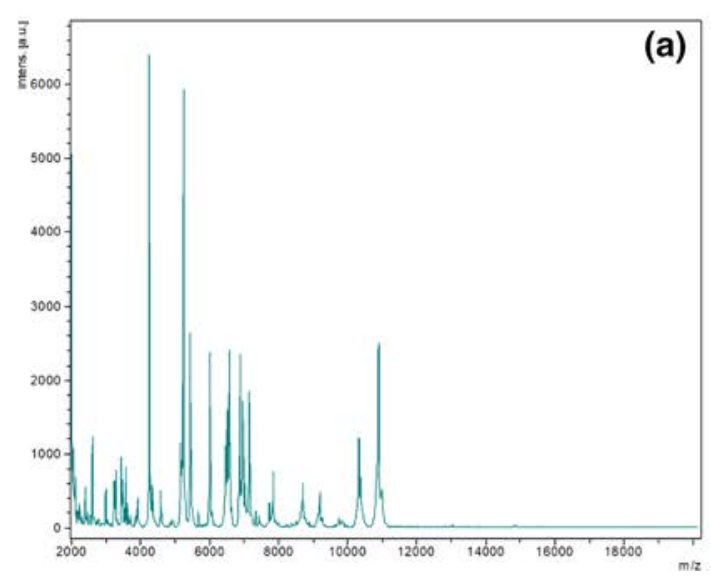

Fig. 2 a Reference mass spectrum from Ezakiella massiliensis strain Marseille-P2951 ${ }^{\mathrm{T}}$ spectra. b Gel view comparing the Ezakiella massiliensis strain Marseille-P2951 ${ }^{\mathrm{T}}$ to other species within the family. The gel view displays the raw spectra of loaded spectrum files arranged in a pseudo-gel-like look. The $x$-axis records the $\mathrm{m} / \mathrm{z}$

\section{Genome Properties}

The draft genome of strain Marseille-P2951 ${ }^{\mathrm{T}}$ is $1,741,785 \mathrm{bp}$ long with $36.69 \%$ of $\mathrm{G}+\mathrm{C}$ content (Table 3; Fig. 3). It is composed of 1 scaffold (composed of 1 contig). Of the 1657 predicted genes, 1606 were protein-coding genes and 51 were RNAs (6 genes are rRNA, 45 genes are tRNA). A total of 1123 genes $(69.93 \%)$ were assigned a putative function and 127 genes were identified as ORFans (7.91\%). Tables 3 and 4 summarize the genome statistics and the distribution of genes into COG (Clusters of Orthologous Groups) functional categories, respectively.

\section{Genomic Comparison}

The comparison of the genome of strain Marseille-P2951 with those of Ezakiella peruensis and other Gram-positive anaerobic cocci is detailed in supplementary Table S1. The distribution of genes into COG categories was similar among all compared genomes (Supplementary Figure S2). However, there were fewer genes of strain Marseille-P2951 ${ }^{\mathrm{T}}$ present in the COG categories C (Energy production and conversion) and $\mathrm{G}$ (Carbohydrate transport and metabolism) than other compared species. In addition, the AGIOS analysis revealed that strain Marseille-P2951 ${ }^{\mathrm{T}}$ shares 541 orthologous genes with Helcococcus sueciensis and 874 with Ezakiella peruensis (Supplementary Table S2). The analysis of the average percentage of nucleotide sequence identity ranged from 60.10 to $94.20 \%$ with Peptoniphilus coxii and Ezakiella peruensis, respectively (Supplementary Table S2). Moreover, the dDDH of strain Marseille-P2951 ${ }^{\mathrm{T}}$ and its closest species varied between 23.90 and $62 \mathrm{~mol} \%$ value. The left $y$-axis displays the running spectrum number originating from subsequent spectra loading. The peak intensity is expressed by a gray scale scheme code. The right $y$-axis indicates the relation between the color of a peak and its intensity, in arbitrary units. Displayed species are indicated on the left

with Helcococcus kunzii and Anaerococcus tetradius, respectively (Supplementary Table S3).

\section{Discussion}

Only $20 \%$ of vaginal bacteria were identified by culture [15]. The understanding of vaginal flora was enhanced by the use of molecular techniques and culturomics. Molecular methods allowed the detection of uncultured and fastidious bacteria in the vagina, such as bacterial vaginosis-associated bacteria type 1 (BVAB1), BVAB2, and BVAB3 [9]. Also, culturomics concepts enabled the culture of new bacterial species, such as Vaginella massiliensis [4], Olegusella massiliensis [5], Murdochiella vaginalis [6], and Ezakiella massiliensis, reported in this paper.

Ezakiella massiliensis strain Marseille- $\mathrm{P} 2951^{\mathrm{T}}$ is a new member of the genus Ezakiella. The similarity of its $16 \mathrm{~S}$ rRNA gene sequence less than the threshold delineated to distinguish a new species, the difference in the $\mathrm{G}+\mathrm{C}$ content, the AGIOS values, and the GGDC values to $70 \%$ confirmed that strain Marseille-P2951 ${ }^{\mathrm{T}}$ is a distinct species than Ezakiella peruensis. The genus Ezakiella was created in 2015 [25] and contains Gram-positive anaerobic cocci that were detected in diverse human clinical samples. Bacteria of this group were also asaccharolytic. All these characteristics were observed in strain Marseille-P2951 ${ }^{\mathrm{T}}$. 
Table 1 Differential characteristics of Ezakiella massiliensis and phylogenetically related species: Ezakiella peruensis strain $\mathrm{M} 6 . \mathrm{X} 2^{\mathrm{T}}$, Finegoldia magna strain CCUG $17636^{\mathrm{T}}$, Peptoniphilus asaccharo- lyticus strain ATCC 14963, Parvimonas micra CCUG $46357^{\mathrm{T}}$, Helcococcus kunzii NCFB $2900^{\mathrm{T}}$, and Anaerococcus prevotii ATCC $9321^{\mathrm{T}}$ $[2,8,22,25,30]$

\begin{tabular}{|c|c|c|c|c|c|c|c|}
\hline Properties & $\begin{array}{l}\text { Ezakiella } \\
\text { massiliensis }\end{array}$ & $\begin{array}{l}\text { Ezakiella } \\
\text { peruensis }\end{array}$ & $\begin{array}{l}\text { Finegoldia } \\
\text { magna }\end{array}$ & $\begin{array}{l}\text { Peptoniphilus } \\
\text { asaccharolyti- } \\
\text { cus }\end{array}$ & $\begin{array}{l}\text { Parvimonas } \\
\text { micra }\end{array}$ & $\begin{array}{l}\text { Helcococcus } \\
\text { kunzii }\end{array}$ & $\begin{array}{l}\text { Anaerococcus } \\
\text { prevotii }\end{array}$ \\
\hline Cell diameter $(\mu \mathrm{m})$ & 0.7 & $<1$ & $0.8-1.6$ & $0.5-0.9$ & $0.3-0.7$ & na & na \\
\hline Oxygen requirement & Anaerobic & Anaerobic & Anaerobic & Anaerobic & Anaerobic & $\begin{array}{c}\text { Facultatively } \\
\text { anaerobic }\end{array}$ & Anaerobic \\
\hline Gram stain & + & + & + & + & + & + & + \\
\hline Spore formation & - & - & - & - & - & - & na \\
\hline Motility & - & - & - & - & - & - & - \\
\hline $\begin{array}{l}\text { DNA G }+C \text { content } \\
\quad(\mathrm{mol} \%)\end{array}$ & 36.69 & 38,4 & na & 31 & 28.65 & 30 & 33 \\
\hline \multicolumn{8}{|l|}{ Production of } \\
\hline Alkaline phosphatase & + & + & variable & - & + & - & - \\
\hline Indole & + & + & - & variable & - & - & - \\
\hline Catalase & + & - & variable & + & variable & - & + \\
\hline Nitrate reductase & - & - & - & - & - & - & - \\
\hline Urease & - & - & - & - & - & - & $+/-$ \\
\hline$\beta$-galactosidase & - & - & - & - & - & - & - \\
\hline$N$-acetyl-glucosamine & - & - & - & na & - & + & na \\
\hline \multicolumn{8}{|l|}{ Acid from } \\
\hline Mannose & - & - & - & - & - & - & + \\
\hline Glucose & - & - & - & - & - & - & $+/-$ \\
\hline Lactose & - & - & - & - & - & + & - \\
\hline Raffinose & - & - & - & - & - & - & + \\
\hline Habitat & $\begin{array}{l}\text { Vaginal } \\
\text { discharge }\end{array}$ & Human feces & $\begin{array}{l}\text { Human speci- } \\
\text { men }\end{array}$ & $\begin{array}{l}\text { Human speci- } \\
\text { men }\end{array}$ & $\begin{array}{l}\text { Human speci- } \\
\text { men }\end{array}$ & $\begin{array}{l}\text { Human speci- } \\
\text { men }\end{array}$ & $\begin{array}{l}\text { Human speci- } \\
\text { men }\end{array}$ \\
\hline
\end{tabular}

na no available data

+ : positive reaction

-: negative reaction

Table 2 Cellular fatty acid profiles (\%) of Ezakiella massiliensis strain Marseille-P2951 ${ }^{\mathrm{T}}$ (data from this study) compared with closest species [25]

\begin{tabular}{|c|c|c|c|c|c|c|c|}
\hline Fatty acid & $\begin{array}{l}\text { Ezakiella } \\
\text { massiliensis }\end{array}$ & $\begin{array}{l}\text { Ezakiella } \\
\text { peruensis }\end{array}$ & $\begin{array}{l}\text { Finegoldia } \\
\text { magna }\end{array}$ & $\begin{array}{l}\text { Peptoniphilus asac- } \\
\text { charolyticus }\end{array}$ & $\begin{array}{l}\text { Parvimonas } \\
\text { micra }\end{array}$ & $\begin{array}{l}\text { Helcococcus } \\
\text { kunzii }\end{array}$ & $\begin{array}{l}\text { Anae- } \\
\text { rococcus } \\
\text { prevotii }\end{array}$ \\
\hline C10:0 & - & 7.3 & 9.4 & - & - & - & - \\
\hline C12:0 & - & & 4.8 & 12.0 & - & - & - \\
\hline C14:0 & 6.9 & 3.0 & 5.9 & 5.4 & 1.6 & 2.5 & 2.0 \\
\hline Iso- $\mathrm{C}_{15: 0}$ & - & - & - & 2.6 & - & - & - \\
\hline C16:0 & 21.8 & 18.3 & 17.6 & 14.4 & 13.4 & 30.0 & 17.1 \\
\hline $\mathrm{C} 17: 0$ & & 5.2 & & - & - & - & - \\
\hline Anteiso- $\mathrm{C}_{17: 0}$ & 1.3 & - & 4.5 & 1.6 & - & - & 1.7 \\
\hline Iso-C17:1/C16:0 DMA & - & - & 18.2 & - & - & - & - \\
\hline C18:0 & 5.0 & - & - & 9.4 & 6.8 & 16.0 & 11.5 \\
\hline $\mathrm{C} 18: 1 \omega 7 \mathrm{c}$ & - & 4.2 & - & - & - & - & - \\
\hline $\mathrm{C}_{18: 1} \omega 9 \mathrm{c}$ & 58.1 & 39.8 & 3.6 & 20.2 & 15.5 & 19.3 & 19.3 \\
\hline 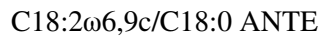 & 4.9 & 13.2 & 5.6 & 22.0 & 58.3 & 29.4 & 20.7 \\
\hline $\mathrm{C}_{18: 1} \omega 9 \mathrm{c} \mathrm{DMA}$ & - & - & 11.1 & 6.6 & - & - & - \\
\hline
\end{tabular}

Bold represents the majority fatty acid for this species; values $<1 \%$ are not shown 


\section{Conclusion}

Phenotypic, phylogenetic, and genomic results confirmed that strain Marseille-P2951 ${ }^{\mathrm{T}}$ is distinct from its phenotypically closest species and can represent a new species, within the genus Ezakiella, for which we proposed the name

Table 3 Nucleotide content and gene count levels of the genome

\begin{tabular}{|c|c|c|}
\hline \multirow[t]{2}{*}{ Attribute } & \multicolumn{2}{|c|}{ Genome (total) } \\
\hline & Value & $\%$ of total ${ }^{\mathrm{a}}$ \\
\hline Size (bp) & $1,741,785$ & 100 \\
\hline $\mathrm{G}+\mathrm{C}$ content $(\mathrm{bp})$ & 639,071 & 36.69 \\
\hline Coding region (bp) & $1,581,924$ & 90.82 \\
\hline Total genes & 1657 & 100 \\
\hline rRNA genes & 6 & 0.36 \\
\hline Protein-coding genes & 1606 & 100 \\
\hline Genes with function prediction & 1123 & 69.93 \\
\hline Genes assigned to COGs & 1029 & 64.07 \\
\hline Genes with peptide signals & 210 & 13.08 \\
\hline Genes with transmembrane helices & 408 & 25.40 \\
\hline
\end{tabular}

${ }^{a}$ The total is based on either the size of the genome in base pairs or the total number of protein-coding genes in the annotated genome
Ezakiella massiliensis. The type strain Marseille-P2951 ${ }^{\mathrm{T}}$ was isolated from the vaginal sample of a healthy woman who had sexual relations with another woman with bacterial vaginosis.

\section{Taxonomic and Nomenclature Proposal}

\section{Description of Ezakiella massiliensis sp. nov.}

Ezakiella massiliensis (mas.si.li.en'sis, L. fem. adj. massiliensis, from Massilia, the Latin name of Marseille where the type strain was first isolated).

Ezakiella massiliensis is non-motile and non-sporulating. It is mesophilic, with optimal growth at $37{ }^{\circ} \mathrm{C}$ after $48 \mathrm{~h}$. Colonies are clear and gray, circular, and convex, with $0.8 \mathrm{~mm}$ of diameter on blood agar. Obligate anaerobe, the cells are gram-positive and coccus-shaped, with a diameter of $0.7 \mu \mathrm{m}$, positive for indole, catalase, and oxidase, negative for nitrate reductase. Gelatin and starch were not hydrolyzed. Lipases, valine arylamidase, trypsin, $\alpha$-chymotrypsin, phosphatase acid, $\alpha$ - and $\beta$-galactosidase, $\beta$-glucuronidase, $\alpha$ - and $\beta$-glucosidase, $N$-acetyl- $\beta$-glucosaminidase were negative, although alkaline phosphatase, leucine arylamidase, and naphthol-AS-BI-phosphohydrolase were positive.
Fig. 3 Graphical circular map of the genome. From outside to the center: Contigs (red/gray), COG category of genes on the forward strand (three circles), genes on forward strand (blue circle), genes on the reverse strand (red circle), COG category on the reverse strand (three circles), $\mathrm{G}+\mathrm{C}$ content. (Color figure online)

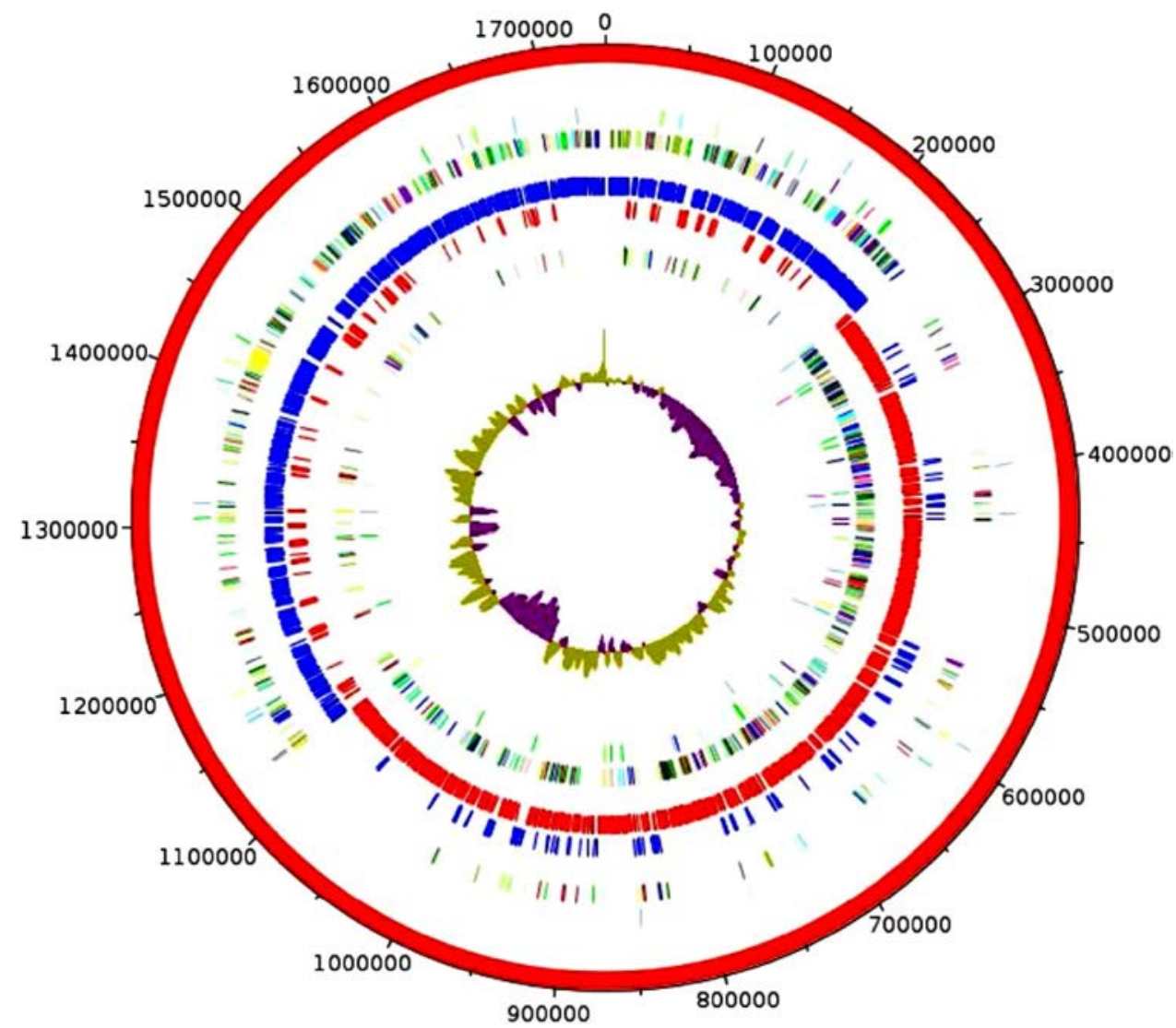


Table 4 Number of genes associated with the 25 general COG functional categories

\begin{tabular}{lrll}
\hline Code & Value & \% of total & Description \\
\hline$[\mathrm{J}]$ & 171 & 10.647572 & Translation \\
{$[\mathrm{A}]$} & 0 & 0 & RNA processing and modification \\
{$[\mathrm{K}]$} & 61 & 3.7982564 & Transcription \\
{$[\mathrm{L}]$} & 59 & 3.6737237 & Replication, recombination, and repair \\
{$[\mathrm{B}]$} & 0 & 0 & Chromatin structure and dynamics \\
{$[\mathrm{D}]$} & 21 & 1.3075966 & Cell cycle control, mitosis and meiosis \\
{$[\mathrm{Y}]$} & 0 & 0 & Nuclear structure \\
{$[\mathrm{V}]$} & 59 & 3.6737237 & Defense mechanisms \\
{$[\mathrm{T}]$} & 36 & 2.241594 & Signal transduction mechanisms \\
{$[\mathrm{M}]$} & 47 & 2.9265256 & Cell wall/membrane biogenesis \\
{$[\mathrm{N}]$} & 5 & 0.3113325 & Cell motility \\
{$[\mathrm{Z}]$} & 0 & 0 & Cytoskeleton \\
{$[\mathrm{W}]$} & 2 & 0.124533 & Extracellular structures \\
{$[\mathrm{U}]$} & 19 & 1.1830635 & Intracellular trafficking and secretion \\
{$[\mathrm{O}]$} & 51 & 3.1755917 & Posttranslational modification, protein turnover, chaperones \\
{$[\mathrm{X}]$} & 21 & 1.3075966 & Mobilome: prophages, transposons \\
{$[\mathrm{C}]$} & 49 & 3.0510585 & Energy production and conversion \\
{$[\mathrm{G}]$} & 36 & 2.241594 & Carbohydrate transport and metabolism \\
{$[\mathrm{E}]$} & 100 & 6.2266498 & Amino acid transport and metabolism \\
{$[\mathrm{F}]$} & 50 & 3.1133249 & Nucleotide transport and metabolism \\
{$[\mathrm{H}]$} & 65 & 4.0473228 & Coenzyme transport and metabolism \\
{$[\mathrm{I}]$} & 31 & 1.9302616 & Lipid transport and metabolism \\
{$[\mathrm{P}]$} & 82 & 5.105853 & Inorganic ion transport and metabolism \\
{$[\mathrm{Q}]$} & 13 & 0.8094645 & Secondary metabolites' biosynthesis, transport, and catabolism \\
{$[\mathrm{R}]$} & 77 & 4.7945204 & General function prediction only \\
{$[\mathrm{S}]$} & 61 & 3.7982564 & Function unknown \\
- & 577 & 35.92777 & Not in COGs \\
\hline & & & \\
\hline & & & \\
\hline
\end{tabular}

It is asaccharolytic; acid is not produced from sugars. The major fatty acids are C18:1n9 (58\%) and C16:0 (22\%). Bacterial cells were susceptible to amoxicillin, ceftriaxone, benzylpenicillin, imipenem, metronidazole, and vancomycin. The genome is $1,741,785$ bp long and the DNA G+C content is $36.69 \mathrm{~mol} \%$. The $16 \mathrm{~S}$ rRNA and genome sequences are both deposited in EMBL/EBI under accession numbers LT576398 and LT635475, respectively. The respective DPD (Digital Protologue Database) TaxonNumber is TA00324. The type strain, strain Marseille-P2951 ${ }^{\mathrm{T}}$ (=CSUR P2951 $=$ DSM 103122), was isolated from the vaginal sample of a healthy woman.

Acknowledgements The authors thank the Xegen Company (http:// www.xegen.fr) for automating the genomic annotation process. We also thank TradOnline for reviewing the English.

Funding This study was supported by Méditerranée Infection and the National Research Agency under the program "Investissements d'avenir," reference ANR-10-IAHU-03.

\section{Compliance with Ethical Standards}

Conflict of interest The authors declare that they have no conflict of interest.

\section{References}

1. Citron DM, Ostovari MI, Karlsson A, Goldstein EJ (1991) Evaluation of the $\mathrm{E}$ test for susceptibility testing of anaerobic bacteria. J Clin Microbiol 29:2197-2203

2. Collins MD, Facklam RR, Rodrigues UM, Ruoff KL (1993) Phylogenetic analysis of some Aerococcus-like organisms from clinical sources: description of Helcococcus kunzii gen. nov., sp. nov. Int J Syst Evol Microbiol 43:425-429

3. Dione N, Sankar SA, Lagier JC, Khelaifia S, Michele C, Armstrong N, Richez M, Abrahão J, Raoult D, Fournier PE (2016) Genome sequence and description of Anaerosalibacter massiliensis sp. nov. New Microbes New Infect 10:66-76

4. Diop K, Bretelle F, Michelle C, Richez M, Rathored J, Raoult D, Fournier PE, Fenollar F (2017) Taxonogenomics and description of Vaginella massiliensis gen. nov., sp. nov., strain Marseille $\mathrm{P} 2517^{\mathrm{T}}$, a new bacterial genus isolated from the human vagina. New Microbes New Infect 15:94-103

5. Diop K, Diop A, Bretelle F, Cadoret F, Michelle C, Richez M, Cocallemen JF, Raoult D, Fournier PE, Fenollar F (2017) 
Olegusella massiliensis gen. nov., sp. nov., strain KHD7T, a new bacterial genus isolated from the female genital tract of a patient with bacterial vaginosis. Anaerobe 44:87-95

6. Diop K, Raoult D, Bretelle F, Fenollar F (2016) "Murdochiella vaginalis" sp. nov., a new bacterial species cultivated from the vaginal flora of a woman with bacterial vaginosis. Hum Microbiome J 2:15-16

7. Drancourt M, Bollet C, Carlioz A, Martelin R, Gayral JP, Raoult D (2000) 16S ribosomal DNA sequence analysis of a large collection of environmental and clinical unidentifiable bacterial isolates. J Clin Microbiol 38:3623-3630

8. Ezaki T, Kawamura Y, Li N, Li ZY, Zhao L, Shu S (2001) Proposal of the genera Anaerococcus gen. nov., Peptoniphilus gen. nov. and Gallicola gen. nov. for members of the genus Peptostreptococcus. Int J Syst Evol Microbiol 51:1521-1528

9. Fredricks DN, Fiedler TL, Marrazzo JM (2005) Molecular identification of bacteria associated with bacterial vaginosis. N Engl J Med 353:1899-1911

10. Gouret P, Paganini J, Dainat J, Louati D, Darbo E, Pontarotti P, Levasseur A (2011) Integration of evolutionary biology concepts for functional annotation and automation of complex research in evolution: the multi-agent software system DAGOBAH. In: Pontarotti P (ed) Evolutionary biology-concepts, biodiversity, macroevolution and genome evolution. Springer, Berlin, pp 71-87

11. Gouret P, Vitiello V, Balandraud N, Gilles A, Pontarotti P, Danchin EG (2005) FIGENIX: intelligent automation of genomic annotation: expertise integration in a new software platform. BMC Bioinform 6:198

12. Kim M, Oh H-S, Park SC, Chun J (2014) Towards a taxonomic coherence between average nucleotide identity and 16S rRNA gene sequence similarity for species demarcation of prokaryotes. Int J Syst Evol Microbiol 64:346-351

13. Lagier JC, Armougom F, Million M, Hugon P, Pagnier I, Robert C, Bittar F, Fournous G, Gimenez G, Maraninchi M, Trape JF, Koonin EV, La Scola B, Raoult D (2012) Microbial culturomics: paradigm shift in the human gut microbiome study. Clin Microbiol Infect 18:1185-1193

14. Lagier JC, Hugon P, Khelaifia S, Fournier PE, La Scola B, Raoult D (2015) The rebirth of culture in microbiology through the example of culturomics to study human gut microbiota. Clin Microbiol Rev 28:237-264

15. Lamont RF, Sobel JD, Akins RA, Hassan SS, Chaiworapongsa T, Kusanovic JP, Romero R (2011) The vaginal microbiome: new information about genital tract flora using molecular based techniques. BJOG 118:533-549

16. LPSN Ezakiella. In: LPSN. http://www.bacterio.net/ezakiella. html. Accessed 26 Jan 2017

17. Matuschek E, Brown DF, Kahlmeter G (2014) Development of the EUCAST disk diffusion antimicrobial susceptibility testing method and its implementation in routine microbiology laboratories. Clin Microbiol Infect 20:O255-O266

18. Menard J, Fenollar F, Henry M, Bretelle F, Raoult D (2008) Molecular quantification of Gardnerella vaginalis and Atopobium vaginae loads to predict bacterial vaginosis. Clin Infect Dis 47:33-43

19. Meier-Kolthoff JP, Auch AF, Klenk HP, Göker M (2013) Genome sequence-based species delimitation with confidence intervals and improved distance functions. BMC Bioinform 14:60

20. Murdoch DA (1998) Gram-positive anaerobic cocci. Clin Microbiol Rev 11:81-120

21. Murdoch DA, Mitchelmore IJ, Tabaqchali S (1994) The clinical importance of gram-positive anaerobic cocci isolated at St Bartholomew's Hospital, London, in 1987. J Med Microbiol 41:36-44

22. Murdoch DA, Shah HN (1999) Reclassification of Peptostreptococcus magnus (Prevot 1933) Holdeman and Moore 1972 as Finegoldia magna. comb.nov. and Peptostreptococcus micros (Prevot 1933) Smith 1957 as Micromonas micros comb. nov.. Anaerobe 5:555-559

23. Murray PR, Baron EJ, Jorgensen JH, Landry ML, Pfaller MA (2007) Manual of clinical microbiology, 9th edn. ASM Press, Washington, D.C.

24. Oren A, Garrity GM (2015) List of new names and new combinations previously effectively, but not validly, published. Int J Syst Evol Microbiol 65:1105-1111

25. Patel NB, Tito RY, Obregón-Tito AJ, O’Neal L, Trujillo-Villaroel O, Marin-Reyes L, Troncoso-Corzo L, Guija-Poma E, Hamada M, Uchino Y, Lewis CM, Lawson PA (2015) Ezakiella peruensis gen. nov., sp. nov. isolated from human fecal sample from a coastal traditional community in Peru. Anaerobe 32:43-48

26. Ramasamy D, Mishra AK, Lagier JC, Padhmanabhan R, Rossi M, Sentausa E, Raoult D, Fournier PE (2014) A polyphasic strategy incorporating genomic data for the taxonomic description of novel bacterial species. Int J Syst Evol Microbiol 64:384-391

27. Sasser M (2006) Bacterial identification by gas chromatographic analysis of fatty acids methyl esters (GC-FAME). MIDI, Technical Note

28. Seng P, Drancourt M, Gouriet F, La Scola B, Fournier P, Rolain JM, Raoult D (2009) Ongoing revolution in bacteriology: routine identification of bacteria by matrix-assisted laser desorption ionization time-of-flight mass spectrometry. Clin Infect Dis 49:543-551

29. Stackebrandt E, Ebers J (2006) Taxonomic parameters revisited: tarnished gold standards. Microbiol Today 33:152

30. Tindall BJ, Euzeby JP (2006) Proposal of Parvimonas gen. nov. and Quatrionicoccus gen. nov. as replacements for the illegitimate, prokaryotic, generic names Micromonas Murdoch and Shah 2000 and Quadricoccus Maszenan et al. 2002, respectively. Int J Syst Evol Microbiol 56:2711-2713 